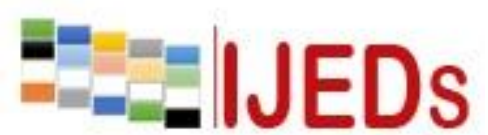

http://ijeds.ppj.unp.ac.id/index.php/IJEDS

\title{
TEACHER'S BEHAVIORS: VERBAL AND NON-VERBAL BEHAVIOR DURING THE ENGLISH CLASSROOM INTERACTION
}

\author{
* Nova Linda ${ }^{1}$, Mukhaiyar ${ }^{2}$ \\ ${ }^{1}$ Graduate Program of English Education, Universitas Negeri Padang, Indonesia \\ ${ }^{2}$ Lecture Master Program English Education, Universitas Negeri Padang,Indonesia \\ Email: novalinda917@gmail.com
}

*Corresponding Author, Received: November 12, 2019, Revised: December 10, 2019, Accepted: December 21, 2019

\begin{abstract}
An effective teacher has to be able to create a good communication between the teacher and the students. It can be seen from teachers behaviour include verbal and non verbal behaviours. In teaching context, teachers convey interaction in the classroom to contribute to interpersonal attraction through teachers' verbal and nonverbal behaviours. This research study explored the teachers' behavior in English classroom interaction. This research design is a qualitative research. Participants were two teachers at English School Indonesia, who taught in two intermediate levels. One teacher was represented for each classroom. The instruments used to collect the data was observation and interview. During the observation, each teacher was observed using video recording. And then the teachers were interviewed to strengthen the result of observation. The research found that both teachers who teach intermediate levels had effective behaviors during the English classroom interaction. The students were motivated to learn English.
\end{abstract}

Keywords : Teacher Verbal Behavior, Teacher Non-Verbal Behavior, Classroom Interaction, and Students' Motivation

\section{INTRODUCTION}

Teaching is not as simple as explaining the lesson, giving exercises and going home. In fact, during teaching-learning process teachers must become familiar with their students' individual situations and changing circumstances. Teacher and students interaction or communication as the most significant factor in determining a teacher's work as successful. 


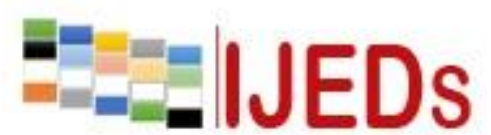

http://ijeds.ppj.unp.ac.id/index.php/IJEDS
International Journal of Educational Dynamics

Vol. 2 No. 1 (pp. 113-123) Desember 2019

p_ISSN 2655-4852

e_ISSN 2655-5093

Communication is an integral part of human lives. People communicate in different ways to express thoughts, feelings, knowledge, skills, and ideas. It could be assumed that communication is through speech and sounds but communication is, in fact, the communication of verbal and non-verbal transmission of knowledge. This is what is called by Richards and Schmidt (2013) stated that communication is the exchange of ideas and information. In communication practice, there is usually at least one speaker or sender to transmit a communication to the receiver.

Teacher-students communication is one of the many factors that could determine effective teaching during classroom interaction. And it also could affect to the students' cognitive learning and feeling. As Richmond and McCroskey in Ballester (2013) stated that Teachers' verbal and non-verbal communicate behaviors become a part of positive affect that influence effective instructional interaction and it directly effects to the students' motivation to learn. This is also in line with what was stated by O'Neill (2009) that most influencing factors in making an effective teaching are creating and bounding a good relationship between teachers and students. Good relationship can be obtained by having a good communication.

Teacher's behavior in communication is the term used for the behavioral manifestation of the act of teaching. It is done for facilitating the learning by students. In classroom management, such relationships of teacher and students are the most significant factor in determining a teacher's work as successful. This is in line with Nasr, Booth and Gillett (1996), who state that teachers are identified as a key factor in creating an effective learning. Specifically, the way the teachers communicate to the students that help determine effective teaching and how the students perceive the teachers' communication might affect their effective and cognitive learning and their feeling throughout the learning process. It means that a good communication requires both competency and experience.

Therefore, in classroom communication teacher should aware not only about the use of verbal communication but also in non-verbal one; teachers should brush up on their verbal and non-verbal communication skills to effectively show students what appropriate classroom behavior means. The majority of teachers' communication with students is nonverbal. Meanwhile, strong verbal communication is significant as well. 


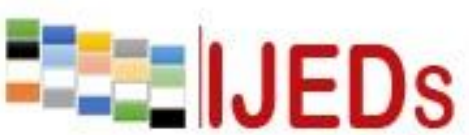

http://ijeds.ppj.unp.ac.id/index.php/IJEDS
International Journal of Educational Dynamics

Vol. 2 No. 1 (pp. 113-123) Desember 2019

p_ISSN 2655-4852

e_ISSN 2655-5093

In other words, non verbal and verbal behaviors are actions that communicate warmth, involvement, psychological closeness, and availability for communication on Davies (2016). Those behaviors determined to breach the barriers that both students and teachers often erect.

Teachers' verbal communication can be defined as the way the teachers communicate with students through speaking and conversation. It is very crucial for the teacher to pay attention to the use of words carefully in order to achieve successful in teaching. Because each of word could provokes a feeling in people, specifics emotions and distinct function. If the teachers applied the words in proper place, it will affect to the soul and body of the students immediately. Therefore, it should be considered by the teachers to avoid using negative words to the students as stated by Gorham in Sutiyatno (2018). Teachers' non verbal behaviour is communication which is more than words include facial expressions, eye contact or lack of eye contact, proximity, and closeness, hand gestures, and body language Miller in Barmaki (2014). It is important for teachers to know well the non-verbal messages they are sending and receiving during the classroom interaction as stated by Barmaki in Sutiyatno (2018). Meanwhile, Chaudry and Arif (2012) argued that non-verbal communication is the unspoken communication that arise in every face to face communication

In classroom interaction, communication is one of crucial things that students and teacher get connected each other, share and give information in two ways, from teacher to students or students to teacher. In fact, communication means the combination of verbal and non-verbal behavior transmission of knowledge. It other words, communication is identified through speech and sounds. It means that, verbal and non-verbal behavior cannot be separated. It implies that non-verbal behavior as a supporting thing that make the verbal behavior become more understandable whenever it is used in English classroom interaction that have students who still have inadequate English mastery. Thus, teachers must be able to combine the two types of communication to be success in teaching. Because the ability of teachers applies them could improve the impression during the classroom interaction. As Witt \& Wheeless (2001) stated that the teacher must have verbal and non-verbal communication skills with their students, to persuade, to resolve the issue, and motivate them. 


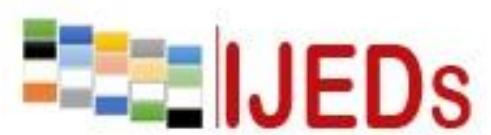

http://ijeds.ppj.unp.ac.id/index.php/IJEDS
International Journal of Educational Dynamics

Vol. 2 No. 1 (pp. 113-123) Desember 2019

p_ISSN 2655-4852

e_ISSN 2655-5093

Therefore, based on the explanation above the researcher felt the need to analyze the how the teacher verbal and non-verbal behavior applied during the English classroom interaction in English School Indonesia (ELSI) at Belanti Radio street no. 12 Padang. Thus, the researcher chose the title "The teachers behavior; verbal and nonverbal behavior during classroom interaction" as the title of the study. As for the purpose of the study was to analyze the teachers' verbal and non-verbal behavior displayed by the teachers in English School Indonesia (ELSI)

\section{METHOD}

The focus of the study is observing the teachers' behavior during the teaching learning process. In this research, the non-verbal and verbal behaviors of the teachers in the process of teaching practice will be observed. Qualitative research is suitable to explore and describe the nature of the research of the research field. As Patton (1990) states qualitative research uses the natural setting as the source of data. The researcher attempted to observe, describe and interpret the setting as they are. The research will be conducted through qualitative. Furthermore, he explains in his book that the first task in qualitative analysis is description. The descriptive analysis answers basic questions. For analyzing of teachers' non-verbal and verbal behaviors these basic descriptive questions in this research included the following; (1) How do teachers at English School Indonesia display their non verbal behaviour during classroom interaction. (2) How do teachers at English School Indonesia display their verbal behaviour during classroom interaction. This research was conducted in English School Indonesia. It is located on jl. A.Yani no. 23 Padang. In this school, there are twelve classrooms and four levels; they are kids, basic, intermediate, advance level. This research was conducted in intermediate levels which were two classes of intermediate level used for the research. The subject of this research is the English teachers in English School Indonesia (ELSI) in Padang. The subject of the research was chosen by using convenience sampling as Sekaran, (2006) states that convenience sampling revers to the collection the information from members of population who are conveniently available to provide it. The total numbers of the subjects are two English teachers. Video recording was used to record teacher-students' interaction and real condition of English classroom interaction, 


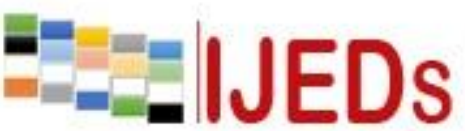

http://ijeds.ppj.unp.ac.id/index.php/IJEDS
International Journal of Educational Dynamics

Vol. 2 No. 1 (pp. 113-123) Desember 2019

p_ISSN 2655-4852

e_ISSN 2655-5093

video recording is aim to identify and observe the types of teacher behaviour used by English teachers in English School Indonesia (ELSI).

\section{RESULTS AND DISCUSSION}

The study was conducted on two teachers in intermediate levels. The researcher came to the classroom and took a video recording to analyze the teachers' verbal and non-verbal behavior displayed during the classroom interaction.

Table1. 1 The result of teachers' verbal behavior displayed by teachers during classroom interaction

\begin{tabular}{|l|c|c|c|}
\hline No & Indicator verbal behavior & $\begin{array}{c}\text { Number of } \\
\text { teachers }\end{array}$ & Percentage \\
\hline 1. & Aceppting feeling & $\mathbf{2}$ & $\mathbf{1 0 0 \%}$ \\
\hline 2. & Praise and encourage & $\mathbf{2}$ & $\mathbf{1 0 0 \%}$ \\
\hline 3. & ccepts and uses ideas of students & $\mathbf{2}$ & $\mathbf{1 0 0 \%}$ \\
\hline 4. & Asking question & $\mathbf{2}$ & $\mathbf{1 0 0 \%}$ \\
\hline 5. & Lecturing & $\mathbf{2}$ & $\mathbf{1 0 0 \%}$ \\
\hline 6. & Giving direction & $\mathbf{2}$ & $\mathbf{1 0 0 \%}$ \\
\hline 7. & Criticizes or justify authority & $\mathbf{2}$ & $\mathbf{1 0 0 \%}$ \\
\hline
\end{tabular}

Accepting feeling was always displayed by teacher A and teacher B. these

teachers displayed this behavior in the opening of classroom interaction to warn up the class. Before starting the class, the teachers asked the students' feeling to make sure the class was gonna be run well. Praise and encourage mostly used by both teachers, teacher A and teacher B. these teachers displayed this behavior during the classroom interaction to give students a reward. This behavior was displayed in whilst teaching activity. Accepts or uses students' ideas was also used by teacher A and Teacher B. This behavior was frequently displayed by teachers in whilst teaching. The teachers directed students' discussion, and accepted their ideas.

Furthermore, asking question was also always displayed by teacher $\mathrm{A}$ and teacher B. This behavior was displayed in every meeting. The teachers displayed this behavior in order to encourage students' comprehending. Then, lecturing and criticize or justify authority are other verbal behaviors that were displayed by teacher A and B. Teacher $\mathrm{A}$ and $\mathrm{B}$ displayed these behaviors in whilst teaching activity, when they explained the lesson and give exercises or speaking practice. The other verbal behavior is giving direction. This verbal behavior was displayed by teacher $\mathrm{A}$ and $\mathrm{B}$. This behavior 


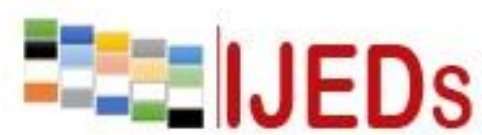

http://ijeds.ppj.unp.ac.id/index.php/IJEDS
International Journal of Educational Dynamics

Vol. 2 No. 1 (pp. 113-123) Desember 2019

p_ISSN 2655-4852

e_ISSN 2655-5093

was used in every meeting. The teachers used this behavior in giving exercises or speaking practice to the students.

\section{Teachers' non-verbal behaviors during classroom interaction}

There are two types of teachers' non-verbal behaviors as explained by Negi (2009) including kinesics and oculesics. There were some of them displayed by both teacher $\mathrm{A}$ and $\mathrm{B}$, except touching on the hand, arm and shoulders. In order to make it more clearly, see this following table of the non-verbal behaviors displayed by teachers during classroom interaction.

Table2. Indicators of teachers' non-verbal behaviors

\begin{tabular}{|l|l|c|c|}
\hline No. & \multicolumn{1}{|c|}{$\begin{array}{c}\text { Indicators teachers' non- } \\
\text { verbal behaviors }\end{array}$} & Number of teachers & Percentage \\
\hline 1. & Smiling & 2 & $100 \%$ \\
\hline 2. & Moving close to another & 2 & $100 \%$ \\
\hline 3. & Facing another & 2 & $100 \%$ \\
\hline 4. & Making eye contact & 2 & $100 \%$ \\
\hline 5. & Leaning toward someone & 2 & $100 \%$ \\
\hline 6. & Gesture & 0 & $100 \%$ \\
\hline 7. & $\begin{array}{l}\text { Touching on the hand, arm or } \\
\text { shoulder. }\end{array}$ & $0 \%$ \\
\hline
\end{tabular}

Table 2 above is the frequency of the non-verbal behaviors displayed by teachers at English School Indonesia (ELSI) in Padang. Smiling is mostly displayed by both teacher $\mathrm{A}$ and $\mathrm{B}$. This behavior was usually displayed in every meeting. The teacher was often smiled to the students from the beginning of the class till the end of the classroom interaction.

\section{Pictures of Teachers' non-verbal behavior during classroom interaction}
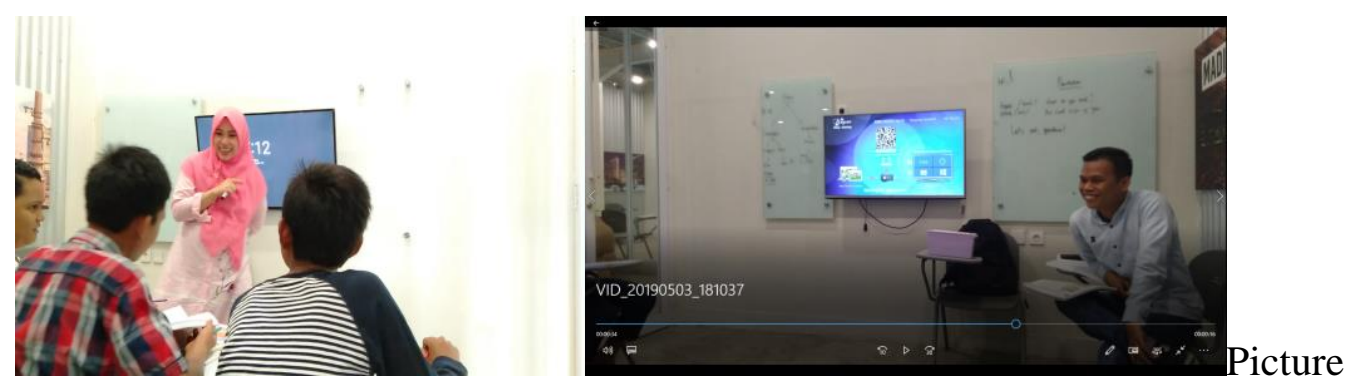

1: teacher A and teacher B smiled to the students. 


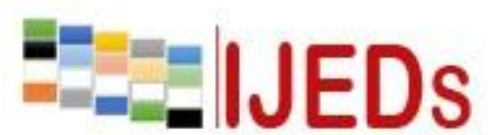

http://ijeds.ppj.unp.ac.id/index.php/IJEDS
International Journal of Educational Dynamics

Vol. 2 No. 1 (pp. 113-123) Desember 2019

p_ISSN 2655-4852

e ISSN 2655-5093

Then, it is followed by moving close to another. This behavior displayed by both teacher A and B. The teachers was displayed this behavior during the classroom interaction from the beginning to the end of the class. The teachers were moving around the class to interact with students.

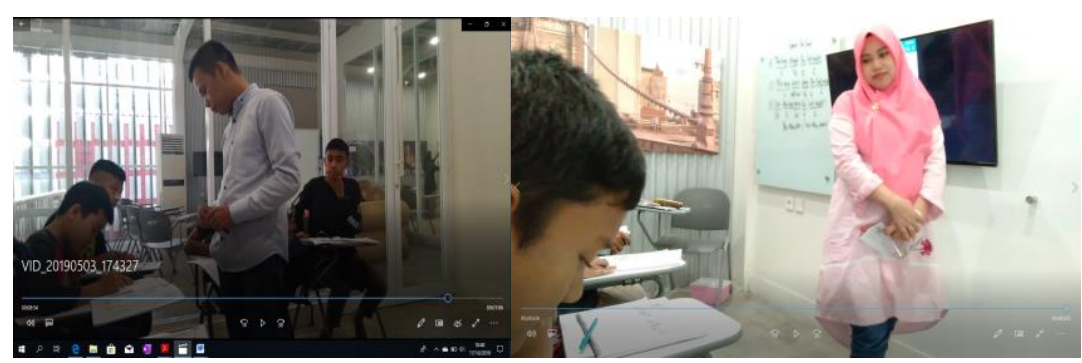

Picture 3: Teacher A and Teacher B moving close to another

Furthermore, facing another was often displayed by both teachers $\mathrm{A}$ and $\mathrm{B}$ in every meeting. This behavior was usually displayed in the opening and whilst teaching. The teachers frequently displayed this behavior in order to create a good communication between teacher and

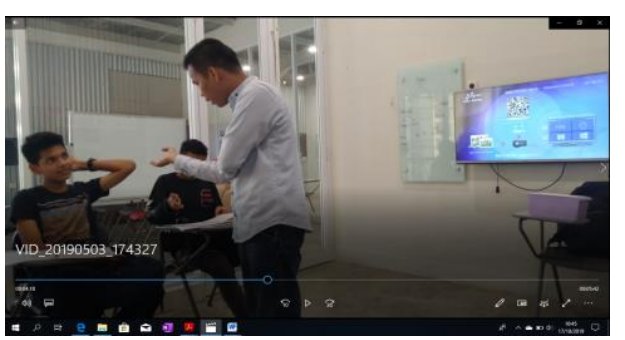

Picture 4: Teacher A and Teacher B were facing one to another student.

Another behavior is making eye contact. This non-verbal behavior mostly displayed by both teacher A and B. Teacher A and B always displayed this behavior in every meeting. This behavior was always displayed in order to interact with the students and control the class.

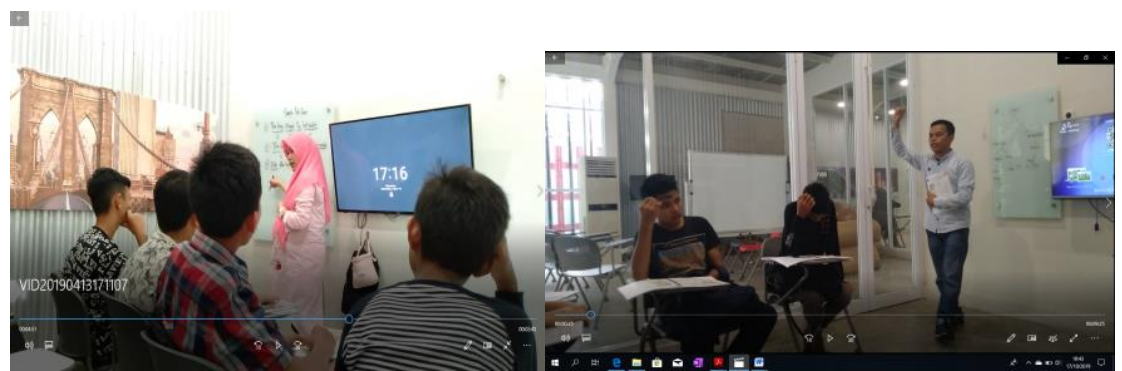

Picture 5: Teacher A and Teacher B making eye contact with the students during classroom interaction. 


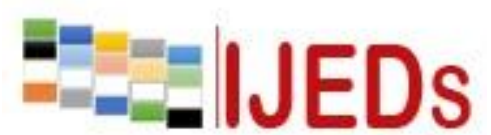

http://ijeds.ppj.unp.ac.id/index.php/IJEDS
International Journal of Educational Dynamics

Vol. 2 No. 1 (pp. 113-123) Desember 2019

p_ISSN 2655-4852

e_ISSN 2655-5093

Additionally, leaning toward someone was often displayed by both teacher A and B. The teachers displayed this behavior in the opening till the end of the classroom interaction. Teacher A and B displayed this behavior in every meeting. When there was a student didn't pay attention to the lesson, the teacher leaned to him/her to give a signal to the student as the student had to pay attention to the teacher.

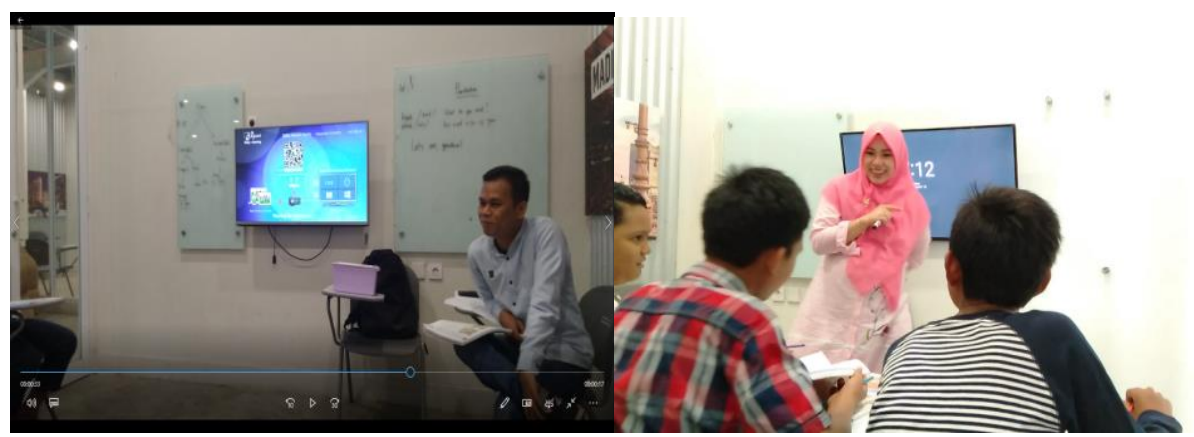

Picture 6: Teacher A and Teacher B are leaning toward a student while making a joke to attract the student' attention.

The next teachers' non-verbal behavior is gesture. Gesture was displayed by both teachers; teacher A and B. The teachers displayed this behavior in every meeting, in the opening of teaching until the end of classroom interaction. This behavior was always displayed in whilst teaching, when the teachers explained the lesson. It was also displayed by teachers when the teachers gave a reward for students' achievement during classroom interaction.

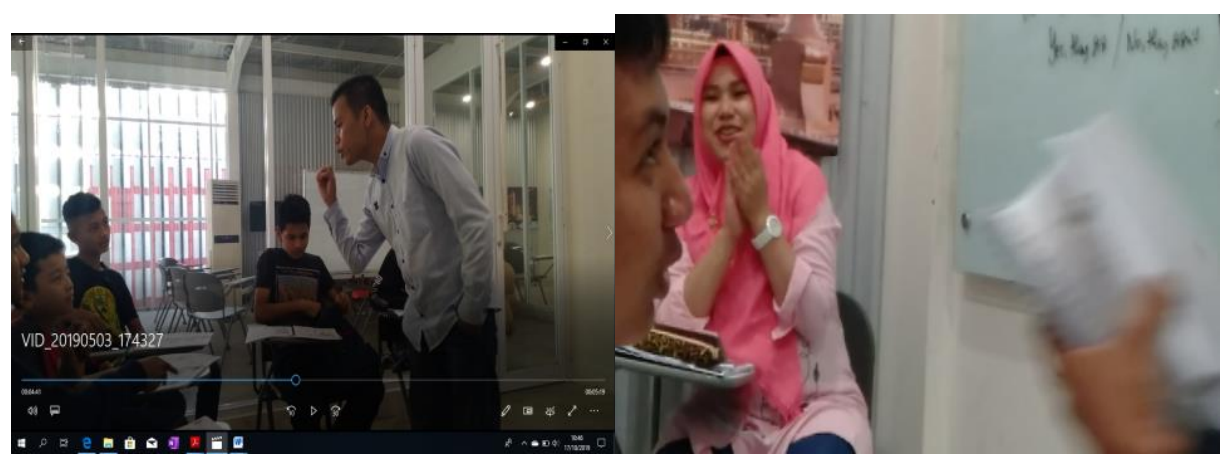

Picture 7: Teacher A and Teacher B are using gesture to give a reward to students and to strengthen their verbal behavior or to guide the students to the meaning of the word.

The last indicator of non-verbal behavior is touching on the hand, arm or shoulder. This behavior was not displayed by both teachers; teacher A and B. The teachers never touch students' hand, arm or shoulder during classroom interaction.. 


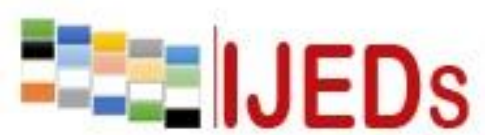

http://ijeds.ppj.unp.ac.id/index.php/IJEDS

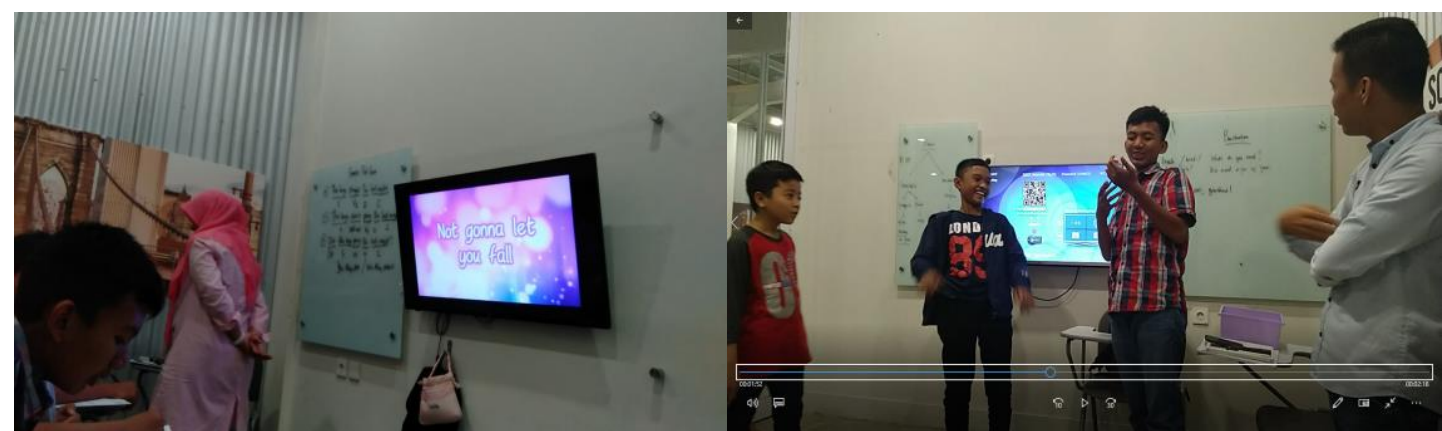

Picture8. Teacher A and Teacher B didn't use touching on the hand, arm or shoulder.

\section{CONCLUSION}

Conclusion based on the result of the data analysis was shown that teacher verbal behavior was displayed well by the teachers at English School Indonesia. It is proven by the display some indicators of teacher verbal behaviors. Accepting feeling mostly displayed by the teacher before starting the class. The word "very good", "excellent" was often used to praise and encourage students during the classroom interaction. Accepted the students' ideas, asking question and lecturing mostly displayed during the classroom interaction. Giving direction was displayed by the teacher, when the teacher asked the students to do the class activity and doing workbook. However, the teachers' non-verbal behaviors in classroom interaction were almost well displayed by the teacher. Smiling was often displayed all the time in every meeting. And it made the students felt enjoy the class as a friendly atmosphere and didn't felt afraid to answer the teacher's question. Moving close to another often did to control the class. However, the teachers didn't touch, on the hand, arm of the students during the classroom interaction, because the teacher argued that they almost never displayed touching behavior to the students' who are intermediate or upper levels. They only often display touching behavior for only kids level. It because their belief of taboo to do that behavior for upper students. Facing another and making eye contact were usually displayed during the classroom interaction by the teacher to the students in every meeting. Moreover, the teacher also leaned toward a student who didn't pay attention to the lesson. The teachers also have clearly purposes in applying those behaviors because of that they know how to apply it during the classroom interaction. Based on the results of the research conducted, the researcher put forward some 


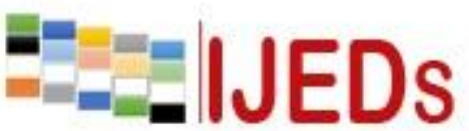

http://ijeds.ppj.unp.ac.id/index.php/IJEDS
International Journal of Educational Dynamics

Vol. 2 No. 1 (pp. 113-123) Desember 2019

p_ISSN 2655-4852

e_ISSN 2655-5093

suggestions as follows: 1) For English teachers, teachers verbal and non-verbal behavior are the kinds of teachers' behavior during classroom interaction that give contribution in English education, especially in students' speaking skill. Therefore, the teachers should aware about the use of their verbal and non-verbal behaviors during classroom interaction, because they could influence students' speaking achievement. (2) For further researcher, it is suggested to conduct deeper researcher about the effect of teachers' verbal and non-verbal behavior in other skills. After that, the next researcher also can more explore the effect of teachers' verbal and non-verbal behavior for other level of students, such as for kids level students who are learn English in earlier period.

\section{REFERENCES}

Barmaki, R. (2014). Nonverbal communication and teaching performance. Proceeding of the 7th International Conference on Educational Data Mining (EDM), 441443.

Behavior Analysis for Effective Teaching. (2009). doi:10.4324/9780203879801.

Chaudry and Arif (2012). Teachers' Nonverbal Behavior and Its Impact on Student Achievement. International Education Studies; Vol. 5, No. 4

Davies, D. J. (2016). Teaching Science Creatively. doi:10.4324/9781315693804.

Negi, Janak Singh. (2009). The Role of Teachers' non-verbal Communication in ELT Classroom.Journal of NELTA Vol. 14 No. 1-2 December 2009, 101-110

Nasr, A. R., Booth, E., \& Gillett, M. (1996). Relationship between lecturers' language background and their teaching performance. Retrieved August 11, 2005, from University of Wollongong, Australia , Faculty of Education Web site: http://www.aare.edu.au/96pap/nasra96151.txt.

Patton, Michel Quin. 1990. Qualitative Evaluation and Research Methods. London: Sage Publications Ltd.

Richards, J. C., \& Schmidt, R. W. (2013). Longman Dictionary of Language Teaching and Applied Linguistics. London, England: Routledge.

Sutiyatno, S. (2018). The Effect of Teacher's Verbal Communication and Non-verbal Communication on Students' English Achievement. Journal of Language Teaching and Research, 9(2), 430. doi:10.17507/j1tr.0902.28

Witt, P.L., \& Wheeless, L. R. (2001). An experimental study of teachers' verbal and nonverbal immediacy and students' affective and cognitive learning. Communication Education, 50, 327-342.

Yaqub, S., Ballester, G., \& Ballester, O. (2013). Frontline Therapy for Multiple Myeloma: A Concise Review of the Evidence Based on Randomized Clinical Trials. Cancer Investigation, 31(8),

529-537. doi:10.3109/07357907.2013.840382 
International Journal of Educational Dynamics

$==-=\mid J E D S$

http://ijeds.ppj.unp.ac.id/index.php/IJEDS
Vol. 2 No. 1 (pp. 113-123) Desember 2019

p_ISSN 2655-4852

e_ISSN 2655-5093 